Full title: A survey of psychiatrists' attitudes towards the physical examination

Short title: Physical examinations in psychiatry

Jonathan Murray ${ }^{1}$, Sarah Baillon ${ }^{2}$, Janet Bruce ${ }^{3}$, Latha Velayudhan ${ }^{1,2}$

${ }^{1}$ The Evington Centre, Leicestershire Partnership NHS Trust

${ }^{2}$ Department of Health Sciences, University of Leicester

${ }^{3}$ The Bradgate Unit, Leicestershire Partnership NHS Trust

This work was carried out in Leicestershire Partnership NHS Trust, Leicester, UK.

Word length of manuscript: 2322 (excluding Abstract, Tables and References)

Corresponding author:

Dr Sarah Baillon

Psychiatry for the Elderly

New Academic Unit

Leicester General Hospital

Gwendolen Road

Leicester, LE5 4PW

Tel. 01162588161

Fax: 01162584078

Email: sfb5@leicester.ac.uk 


\section{A SURVEY OF PSYCHIATRISTS' ATTITUDES TOWARDS THE PHYSICAL EXAMINATION}

\section{ABSTRACT}

Background: Studies have shown that most psychiatric patients do not receive a thorough physical examination (PE).

Methods: Psychiatrists working with Leicestershire Partnership NHS Trust were surveyed to determine factors influencing the performance of PEs, including their attitudes toward conducting them.

Results: Responses from 118/192 (61\%) psychiatrists showed that most (96\%) believe that the PE is important. The majority (72\%) indicated that their PE skills had diminished since working in psychiatry and this was reported more by senior psychiatrists compared to junior trainees ( $85 \%$ vs 40\%). $77 \%$ considered that a patient's mental state should have a bearing on the type of PE the psychiatrist performs.

Conclusions: Likely reasons for poor performance of PEs include: shortage of time and equipment, challenges associated with agitated or uncooperative patients, and possibly a degree of skill atrophy, especially in senior psychiatrists. Further research is needed to investigate if strategies addressing these factors would improve the standard of PEs on psychiatric patients.

Declaration of interest: This survey received no specific funding and all authors have no conflict of interest to report.

Keywords: physical examination, psychiatry, physical health, attitudes, psychiatrists, clinical skills 


\section{BACKGROUND}

The association between mental illness and poor physical health has been recognised for over 70 years (Philips, 1937). The standardised mortality ratios for both natural and unnatural causes are significantly higher in psychiatric patients compared to the general population and recent research suggests that this mortality gap is not closing (Harris \& Barraclough, 1998; Lawrence et al., 2013). Various studies involving the thorough medical evaluation of psychiatric patients have revealed significant rates of physical disease, much of which was previously undetected (Koran et al., 2002). Several reasons have been identified for this comorbidity including unhealthy lifestyle choices, the physical ill-effects of psychotropic medication and the under-utilisation of medical services in general (Druss et al., 2011; Thornicroft, 2011).

The assessment of patients in the psychiatric outpatient clinic or following admission to a psychiatric ward provides an opportunity to check their physical health by taking a history, undertaking a physical examination (PE) and obtaining collateral information. However, many psychiatric patients have difficulty describing their symptoms and are less likely to complain about them than the general population (Phelan et al., 2001). It is therefore important that a PE is performed in order to rule out physical disease as a cause for the patient's psychiatric symptoms and identify coexistent conditions which could hinder the patient's recovery and influence the choice of treatment (Reeves et al., 2000; Waern et al., 2002). A PE at admission enables baseline data to be recorded for comparison should the patient's physical state change at a later stage.

Studies that have evaluated this aspect of care have concluded that most psychiatric patients do not receive a thorough PE (Hodgson \& Adeyemo, 2004; Murray \& Baillon, 2013; Rigby \& Oswald, 1986; Vanezis \& Manns, 2010). Various reasons have been suggested for this shortcoming including: practical obstacles such as shortage of time and equipment, concerns about the re-traumatising effect of the examination on patients who have been abused, a degree of examination 'skill atrophy' 
which may occur as trainees progress through psychiatric training and the general attitude that competency in this area is beyond the repertoire of skills that a psychiatrist should possess (Craddock et al., 2008; Gabbard \& Nadelson, 1995; McIntyre \& Romano, 1977; Mitchell et al., 1998; Read \& Bentall, 2012). Other factors could include the lack of clear gold standards for PE, a misplaced faith in the value of routine investigations, an aversion to performing the examination because it can appear at odds with the other therapeutic aspects of the relationship between the patient and the psychiatrist and, in some cases, a fear of exacerbating the patient's level of agitation and aggression (Murray \& Baillon, 2013). The aim of this study was to determine factors contributing to the underperformance of the PE on psychiatric patients, which would then help to inform efforts to improve standards.

\section{METHOD}

An anonymous paper-based structured questionnaire was distributed to all psychiatrists (including foundation year 2 (doctors in the second year of their Foundation Programme which has to be completed before entering specialist or GP training) and GP trainees (doctors completing the psychiatric part of their vocational training scheme) who perform similar duties to core psychiatric trainees) working for Leicestershire Partnership NHS Trust between $1^{\text {st }}$ January 2012 and $31^{\text {st }}$ May 2012. The questionnaire obtained background information about the respondent and then included questions with categorical and Likert scale responses, providing space for free-text comments. Questions were based on a range of issues identified from a review of the literature and from conducting a previous study of the subject (Murray \& Baillon, 2013). All data were analysed descriptively using IBM SPSS Statistics version 20. Univariate analyses were used to find significant associations between demographic data and item responses using Chi-squared tests and Fisher's exact tests when the expected cell value was less than 5.

\section{RESULTS}


The overall response rate was $61 \%(118 / 192)$ but this varied considerably according to the subspecialty and rank. The highest response rate was in Old Age Psychiatry (33/36, 92\%), followed by Learning Disabilities (9/14, 64\%), General Adult (71/117, 61\%) and Child and Adolescent Psychiatry $(5 / 25,20 \%)$. The response rate was highest amongst non-consultant career grade (nontraining) psychiatrists $(13 / 15,87 \%)$ followed by senior trainees $(24 / 36,67 \%)$, junior trainees $(35 / 54$, $65 \%)$ and lowest amongst the consultants $(46 / 87,52 \%)$.

The age and length of experience of the respondents varied considerably - over half (55\%) were aged less than 40 years and had 10 years or less of psychiatric experience $(59 / 116,51 \%)$. Female respondents were in a minority $(48 / 117,41 \%)$ although they formed a higher proportion of the junior trainee group $(19 / 35,54 \%)$ compared to the other ranks combined $(29 / 82,35 \%)$ (Pearson Chisquared $=3.6, d f=1, P<0.01$ ). Comparisons were not made between the subspecialties of Child Psychiatry, Learning Disabilities and the other subspecialties due to the low number of respondents in those groups.

[Position Table 1 at some point after this]

Table 1 shows the frequencies of responses to many items of the questionnaire. The majority of respondents $(113 / 118,96 \%)$ regarded the PE as 'essential' or 'important', and $69 \%(81 / 117)$ felt that the PE of inpatients was more important than examination of outpatients, largely because following admission to hospital the psychiatric team are responsible for the patients' physical healthcare. Two thirds of the respondents $(79 / 118,67 \%)$ indicated that they routinely perform PEs. This group contained a significantly higher proportion of junior trainees $(34 / 35,97 \%)$ compared to all other doctors grouped together $(45 / 83,54 \%)$ (Pearson Chi-squared $=20.5, \mathrm{df}=1, \mathrm{P}<0.001)$, and more Old Age psychiatrists $(29 / 34,85 \%)$ compared to General Adult psychiatrists $(42 / 70,60 \%)$ (Pearson Chisquared $=6.8, \mathrm{df}=1, \mathrm{P}<0.01)$. 
$30 \%(24 / 80)$ of the respondents stated that they usually or sometimes felt intimidated whilst performing a PE on a psychiatric patient. This group contained a higher proportion of female doctors $(16 / 32,50 \%)$ (Pearson Chi-squared $=10.2, d f=1, P<0.001)$, and junior trainees $(18 / 34$, 53\%) $($ Pearson Chi-squared $=14.8, d f=1, P<0.001)$. When asked whether a patient had ever reacted violently towards them during a PE 29\% (34/118) of respondents answered 'Yes'. This group comprised a significantly higher proportion of females $(20 / 28,71 \%)$ (Pearson Chi-squared $=6.3, d f=1$, $\mathrm{P}<0.01)$ and more Old Age psychiatrists $(15 / 34,44 \%)$ compared to General Adult psychiatrists $(16 / 70,23 \%)($ Pearson Chi-squared $=4.9, d f=1, P<0.05) .77 \%(89 / 100)$ of respondents indicated that a patient's mental state should have a bearing on the type of PE the psychiatrist performs, and the majority indicated that PE of intimate parts should only be conducted if the patient complains of symptoms.

Over half of respondents $(63 / 112,56 \%)$ rated their proficiency in performing the PE as 'very good' or 'good', $40 \%$ rated it as 'mediocre', and $4 \%$ as 'poor'. A significantly higher proportion of junior trainees $(26 / 34,76 \%)$ rated their proficiency 'very good' or 'good' than other doctors $(37 / 78,47 \%)$ (Pearson Chi-squared $=13.3, \mathrm{df}=3, \mathrm{P}<0.01)$. Almost three quarters of respondents $(84 / 117,72 \%)$ felt that their PE skills had diminished since starting work in psychiatry. This group included a significantly higher proportion of senior doctors $(70 / 82,85 \%)$ than junior trainees $(14 / 35,40 \%)$ (Pearson Chi-squared $=24.9, \mathrm{df}=1, \mathrm{P}<0.001$ ). Despite this, over two-thirds of the respondents (79/116, 68\%) were opposed to the PE of patients being carried out by another health professional such as a physician or nurse practitioner.

\section{DISCUSSION}

This study sheds some light upon the factors contributing to the standard of PEs performed on psychiatric patients. The results show that most psychiatrists view PE as important, believe skills in 
this domain should be part of their core competencies and that the procedure should be carried out by themselves rather than another health professional. The majority of junior psychiatrists, who carry out the bulk of PEs, rated their PE competencies as good. The survey responses also indicate that psychiatrists do not dislike carrying out PEs, view it as important as the history or laboratory investigations, and do not generally believe that it has a detrimental effect on the patient or on his or her relationship with the psychiatrist. In addition, the survey showed that most (80\%) psychiatrists are in favour of using structured forms to document the PE findings, a practice which has been demonstrated to increase the amount of clinical information recorded (Murray \& Baillon, 2013).

The study identified several factors likely to be contributing to underperformance of PEs including insufficient time when performing a PE in outpatient clinics (62\%), inadequate examination equipment in both the clinics (69\%) and on the wards (43\%) and intimidation by aggressive or agitated patients with consequent limitation of the PE to a few critical items. One respondent suggested that junior trainees may find the PE incongruent with the long psychiatric history. $72 \%$ of the respondents stated that they felt their PE skills had diminished since starting work in psychiatry, although the majority of these doctors did not rate their proficiency in this area as poor. A much higher proportion of senior psychiatrists, compared to junior trainees, felt that their skills had diminished.

A recent survey of the use of direct observation in a Canadian psychiatric training program revealed that PE skills are observed less frequently than skills in other clinical contexts and so it is possible that junior trainees receive insufficient supervison in this area (Madan et al., 2012). The barriers to observation of trainees' skills mentioned by respondents included scheduling challenges, competing demands, and difficulty incorporating direct observation into an existing structure. Understandably, 
poor standards may be overlooked if there is inadequate supervision for PE skills and further research into this would be beneficial.

\section{Limitations}

Sixty-one percent of doctors working in the Trust responded to this survey and it is possible that those who did not participate have different attitudes on these issues. The small numbers of respondents from the subspecialties of Learning Disabilities and Child Psychiatry meant that these groups were under-represented and it was not possible to compare the responses of doctors in those groups with those working in General Adults and Old Age psychiatry. This problem could be overcome by conducting a larger regional or national survey of psychiatrists, and would demonstrate if there are specific issues and variations between Trusts.

Another limitation of the study was the absence of any questions specifically relating to how often PE findings are mentioned when new patients are discussed on ward rounds, or any questions relating to the frequency or quality of supervision junior doctors receive regarding their PE skills.

\section{Implications for clinical practice}

So what can be done to address the causative factors identified in this survey? One factor was the shortage of equipment for PE of inpatients. This could be addressed by giving certain staff members the responsibility of ensuring all wards and clinic rooms have a full complement of maintained PE equipment and regularly auditing this.

This survey indicated that psychiatrists often face difficulties when conducting PEs on agitated and sometimes hostile psychiatric patients. The Royal College of Psychiatrists' recommend that every patient should have a comprehensive PE within 24 hours of admission, and that a full physical health review should be completed during the first 2 weeks (The Royal College of Psychiatrists, 2009). Most 
of the respondents in this survey (77\%) indicated that the PE should be tailored according to the patient's mental state, often stating that it would be unwise for a doctor to persist with a full PE when it was likely to increase the risk of a violent incident. Clearly a level of professional judgement is required to determine when a PE needs to be curtailed in response to a patient's mental state or extended according to the history and the use of 'red flags'.

An examining doctor should conduct an appropriate PE based upon the patient's mental state, physical health needs and level of cooperation and these could be categorised into three types upon which gold standards could be based:

1) A comprehensive or full examination undertaken when the patient is calm and cooperative;

2) A limited or partial examination (containing critical items only) carried out when the patient is compliant but too agitated to tolerate a complete examination;

3) An external inspection only, performed when the patient is totally uncooperative or too hostile to allow any direct physical contact (Garden, 2005; Murray \& Baillon, 2013; The Royal College of Psychiatrists, 2009).

The survey results suggest that junior trainees would welcome and benefit from a teaching session on PE in psychiatry during their induction course. This session could include guidance outlining how best to tailor the PE to the patient's needs and mental state. This would also be a good time to impress upon the trainees the importance of revisiting the patient to do a comprehensive examination if the patient did not receive one on admission.

The majority (86\%) of respondents felt that it was possible for psychiatrists to maintain or improve their skills and that they should have to do this throughout their career. Various ways of maintaining skills were suggested, including performing PEs on all new outpatients, attending refresher courses on the subject, including the PE in workplace-based assessments, and engaging in peer-review 
sessions with local physicians. One respondent suggested greater use should be made of educational aids such as the Royal College of Psychiatrists' CPD online learning modules on the PE (The Royal College of Psychiatrists).

\section{Conclusion}

The marked inequality in physical health between psychiatric patients and the general population is currently a major topic of discussion and last year a national financial incentive was introduced aimed at improving the physical health care of patients with mental illness (NHS England, 2014). Whilst there are a variety of factors that contribute to the poorer physical health in psychiatric patients this survey has highlighted a number of issues relating to one aspect of this problem - the underperformance of PEs in psychiatric patients. Further research and audit is needed to investigate whether strategies addressing these issues would improve the standard of PEs on psychiatric patients. Regular training programmes and guidelines are also important for psychiatrists at all levels to ensure competency and high quality physical health care for their patients.

\section{REFERENCES}

Craddock, N., Antebi, D., Attenburrow, M-J., Bailey, A., Carson, A., Cowen, P., Craddock, B., Eagles, J., Ebmeier, K., Farmer, A., et al. (2008) Wake up call for British Psychiatry. British Journal of Psychiatry, 193, 6-9.

Druss, B.G., Zhao, L., Von Esenwein, S., Morrato, E.H. \& Marcus, S.C. (2011) Understanding excess mortality in persons with mental illness: 17-year follow up of a nationally representative US survey. Medical Care, 49, 599-604.

Gabbard, G.O. \& Nadelson, C. (1995) Professional boundaries in the physician-patient relationship.[Erratum appears in JAMA 1995 Nov 1;274(17):1346]. Journal of the American Medical Association, 273, 1445-1449. 
Garden, G. (2005) Physical examination in psychiatric practice. Advances in Psychiatric Treatment, $11,142-149$.

Harris, E. \& Barraclough, B. (1998) Excess mortality of mental disorder. British Journal of Psychiatry, $173,11-53$.

Hodgson, R. \& Adeyemo, O. (2004) Physical examination performed by psychiatrists. International Journal of Psychiatry in Clinical Practice, 8, 57-60.

Koran, L.M., Sheline, Y., Imai, K., Kelsey, T.G., Freedland, K.E., Mathews, J. \& Moore, M. (2002) Medical disorders among patients admitted to a public-sector psychiatric inpatient unit. Psychiatric Services, 53, 1623-1625.

Lawrence, D., Hancock, K.J. \& Kisely, S. (2013) The gap in life expectancy from preventable physical illness in psychiatric patients in Western Australia: retrospective analysis of population based registers. British Medical Journal, 346, f2539.

Madan, R., Conn, D., Dubo, E., Voore, P. \& Wiesenfeld, L. (2012) The enablers and barriers to the use of direct observation of trainee clinical skills by supervising faculty in a psychiatry residency program. Canadian Journal of Psychiatry, 57, 269-272.

McIntyre, J.S. \& Romano, J. (1977) Is there a stethoscope in the house (and is it used)? Archives of General Psychiatry, 34, 1147-1151.

Mitchell, A., McCabe, E. \& Brown, K. (1998) Psychiatrists' attitudes to physical examination of new outpatients with major depressive disorder. Psychiatric Bulletin, 22, 82-84.

Murray, J. \& Baillon, S. (2013) A case series of physical examinations on psychiatric inpatients: influence of a structured form on the quality of documentation. Journal of Mental Health, 22, 428438.

NHS England (2014) Mental health staff to introduce physical 'MOT' to reduce deaths. http://www.england.nhs.uk/2014/05/15/physical-mot/ .

Phelan, M., Stradins, L. \& Morrison, S. (2001) Physical health of people with severe mental illness. British Medical Journal, 322, 443-444. 
Philips, R. (1937) Physical disorder in 164 consecutive admissions to a mental hospital: the incidence and significance. British Medical Journal, 2, 363-366.

Read, J. \& Bentall, R.P. (2012) Negative childhood experiences and mental health: theoretical, clinical and primary prevention implications. British Journal of Psychiatry, 200, 89-91.

Reeves, R.R., Pendarvis, E.J. \& Kimble, R. (2000) Unrecognized medical emergencies admitted to psychiatric units. American Journal of Emergency Medicine, 18, 390-393.

Rigby, J.C. \& Oswald, A.G. (1986) An evaluation of the performing and recording of physical examinations by psychiatric trainees. British Journal of Psychiatry, 150, 533-535.

The Royal College of Psychiatrists (2014) Physical examinations in psychiatric practice. CPD online. The online learning resource for mental health professionals.

http://www.psychiatrycpd.co.uk/learningmodules/physicalexaminationinpsychi.aspx, Date of access $19 / 02 / 2014$

The Royal College of Psychiatrists (2009) Physical health in mental health. Final report of a scoping group. Occasional Paper OP67. London: Royal College of Psychiatrists.

Thornicroft, G. (2011) Physical health disparities and mental illness: the scandal of premature mortality. British Journal of Psychiatry, 199, 441-442.

Vanezis, A. \& Manns, D. (2010) Physical examinations of mental health services users. Progress in Neurology and Psychiatry, 14, 19-23.

Waern, M., Rubenowitz, E., Runeson, B., Skoog, I., Wilhelmson, K. \& Allebeck, P. (2002) Burden of illness and suicide in elderly people: case-control study. British Medical Journal, 324, 1355. 
Table 1 - Frequency of survey question responses (Total sample $=118$ )

\begin{tabular}{|c|c|c|c|}
\hline Item & Response & $\mathbf{N}$ & Freq (valid \%) \\
\hline How would you rate the importance of the physical examination in psychiatry? & $\begin{array}{l}\text { Essential } \\
\text { Important } \\
\text { Slightly useful } \\
\text { Unimportant } \\
\text { Totally irrelevant }\end{array}$ & 118 & $\begin{array}{l}81(69) \\
32(27) \\
4(3) \\
1(1) \\
0\end{array}$ \\
\hline $\begin{array}{l}\text { How do you regard the importance of the physical examination as compared to the physical } \\
\text { history? }\end{array}$ & $\begin{array}{l}\text { More important } \\
\text { Equally important } \\
\text { Less important }\end{array}$ & 117 & $\begin{array}{l}15(13) \\
85(72) \\
17(15) \\
\end{array}$ \\
\hline $\begin{array}{l}\text { How do you regard the importance of the physical examination in the assessment of a psychiatric } \\
\text { patient as compared to routine laboratory screening tests e.g. FBC, Urinalysis? }\end{array}$ & $\begin{array}{l}\text { More important } \\
\text { Equally important } \\
\text { Less important }\end{array}$ & 118 & $\begin{array}{l}34(29) \\
78(66) \\
6(5) \\
\end{array}$ \\
\hline $\begin{array}{l}\text { How do you regard the importance of the physical examination in the assessment of a psychiatric } \\
\text { inpatient as compared to the psychiatric outpatient? }\end{array}$ & $\begin{array}{l}\text { More important } \\
\text { Equally important } \\
\text { Less important }\end{array}$ & 117 & $\begin{array}{l}81(69) \\
33(28) \\
3(3)\end{array}$ \\
\hline In your current job, do you perform physical examinations? & $\begin{array}{l}\text { Yes } \\
\text { No }\end{array}$ & 118 & $\begin{array}{l}79(67) \\
39(33)\end{array}$ \\
\hline $\begin{array}{l}\text { Whilst performing a physical examination in the outpatient clinic, do you have: } \\
-\quad \text { Adequate time? } \\
-\quad \text { Examination couch? } \\
-\quad \text { Adequate equipment? } \\
-\quad \text { Access to a chaperone? } \\
-\quad \text { Structured form to record the findings? }\end{array}$ & $\begin{array}{l}\text { Yes } \\
\text { Yes } \\
\text { Yes } \\
\text { Yes } \\
\text { Yes }\end{array}$ & $\begin{array}{l}65 \\
65 \\
65 \\
65 \\
65 \\
\end{array}$ & $\begin{array}{l}25(38) \\
23(35) \\
20(31) \\
36(55) \\
10(15) \\
\end{array}$ \\
\hline $\begin{array}{l}\text { Whilst performing a physical examination on the psychiatric ward, do you have: } \\
-\quad \text { Adequate time? } \\
-\quad \text { Examination couch? } \\
-\quad \text { Adequate equipment? } \\
-\quad \text { Access to a chaperone? } \\
-\quad \text { Structured form to record the findings? }\end{array}$ & $\begin{array}{l}\text { Yes } \\
\text { Yes } \\
\text { Yes } \\
\text { Yes } \\
\text { Yes }\end{array}$ & $\begin{array}{l}53 \\
53 \\
53 \\
53 \\
52\end{array}$ & $\begin{array}{l}51(96) \\
49(92) \\
30(57) \\
52(98) \\
45(87) \\
\end{array}$ \\
\hline $\begin{array}{l}\text { Whilst performing a physical examination on a psychiatric patient how often do you feel } \\
\text { intimidated? }\end{array}$ & $\begin{array}{l}\text { Always } \\
\text { Usually } \\
\text { Sometimes } \\
\text { Rarely } \\
\text { Never }\end{array}$ & 80 & $\begin{array}{l}0 \\
1(1) \\
23(29) \\
42(53) \\
14(18) \\
\end{array}$ \\
\hline If you felt intimidated by a patient you were examining, would this alter your practice in any way? & $\begin{array}{l}\text { Yes } \\
\text { No }\end{array}$ & 73 & $\begin{array}{l}59(81) \\
14(19)\end{array}$ \\
\hline
\end{tabular}




\begin{tabular}{|c|c|c|c|}
\hline How would you describe the reaction of most patients to the physical examination? & $\begin{array}{l}\text { Very positive } \\
\text { Positive } \\
\text { Neutral } \\
\text { Negative } \\
\text { Very negative }\end{array}$ & 80 & $\begin{array}{l}4(5) \\
39(49) \\
35(44) \\
2(2) \\
0\end{array}$ \\
\hline $\begin{array}{l}\text { Do you think that a patient's mental state should have a bearing on the type of physical } \\
\text { examination that a psychiatrist performs? } \\
\text { If Yes; what psychopathology would lead you to defer a comprehensive examination in favour of } \\
\text { a) a partial/limited PE (involving some physical contact) b) external inspection only? }\end{array}$ & $\begin{array}{l}\text { Yes } \\
\text { No }\end{array}$ & 116 & $\begin{array}{l}89(77) \\
27(23)\end{array}$ \\
\hline $\begin{array}{l}\text { During a comprehensive physical examination of a psychiatric patient, in what circumstances } \\
\text { should (you may choose more than one option): } \\
\text { (a) The female breasts be examined? }\end{array}$ & $\begin{array}{l}\text { Always } \\
\text { If the patient is over } 65 \text { years old } \\
\text { If the patient is over } 50 \text { years old } \\
\text { If the patient complains of symptoms } \\
\text { If the patient is over } 65 \text { and has symptoms } \\
\text { If the patient is over } 50 \text { and has symptoms } \\
\text { Never }\end{array}$ & 115 & $\begin{array}{l}9(8) \\
1(1) \\
1(1) \\
77(67) \\
4(3) \\
5(4) \\
18(16)\end{array}$ \\
\hline (b) The male genitalia be examined? & $\begin{array}{l}\text { Always } \\
\text { If the patient is over } 65 \text { years old } \\
\text { If the patient is over } 50 \text { years old } \\
\text { If the patient complains of symptoms } \\
\text { If the patient is over } 65 \text { and has symptoms } \\
\text { If the patient is over } 50 \text { and has symptoms } \\
\text { Never }\end{array}$ & & $\begin{array}{l}5(4) \\
0 \\
0 \\
95(83) \\
0 \\
2(2) \\
13(11)\end{array}$ \\
\hline (c) A rectal examination be performed? & $\begin{array}{l}\text { Always } \\
\text { If the patient is over } 65 \text { years old } \\
\text { If the patient is over } 50 \text { years old } \\
\text { If the patient complains of symptoms } \\
\text { If the patient is over } 65 \text { and has symptoms } \\
\text { If the patient is over } 50 \text { and has symptoms } \\
\text { Never }\end{array}$ & & $\begin{array}{l}4(3) \\
0 \\
0 \\
85(74) \\
2(2) \\
3(3) \\
22(19)\end{array}$ \\
\hline (d) A vaginal examination be performed? & $\begin{array}{l}\text { Always } \\
\text { If the patient is over } 65 \text { years old } \\
\text { If the patient is over } 50 \text { years old } \\
\text { If the patient complains of symptoms } \\
\text { If the patient is over } 65 \text { and has symptoms }\end{array}$ & & $\begin{array}{l}2(2) \\
0 \\
0 \\
78(68) \\
0\end{array}$ \\
\hline
\end{tabular}




\begin{tabular}{|c|c|c|c|}
\hline & $\begin{array}{l}\text { If the patient is over } 50 \text { and has symptoms } \\
\text { Never }\end{array}$ & & $\begin{array}{l}1(1) \\
35(30)\end{array}$ \\
\hline $\begin{array}{l}\text { In your opinion what effect does the physical examination have on the level of trust that the } \\
\text { patient has in the psychiatrist/psychiatric team? }\end{array}$ & $\begin{array}{l}\text { Significant increase } \\
\text { Slight increase } \\
\text { No effect } \\
\text { Slight decrease } \\
\text { Significant decrease }\end{array}$ & 104 & $\begin{array}{l}23(22) \\
49(47) \\
31(30) \\
1(1) \\
0\end{array}$ \\
\hline Has a patient ever reacted violently towards you during a physical examination? & $\begin{array}{l}\text { Yes } \\
\text { No }\end{array}$ & 118 & $\begin{array}{l}34(29) \\
84(71)\end{array}$ \\
\hline $\begin{array}{l}\text { Are you in favour of using a structured form (proforma) to record the findings of the physical } \\
\text { examination? }\end{array}$ & $\begin{array}{l}\text { Yes } \\
\text { No }\end{array}$ & 117 & $\begin{array}{l}94(80) \\
23(20)\end{array}$ \\
\hline $\begin{array}{l}\text { How would you rate your proficiency in performing a physical examination of a psychiatric } \\
\text { patient? }\end{array}$ & $\begin{array}{l}\text { Very good } \\
\text { Good } \\
\text { Mediocre } \\
\text { Poor } \\
\text { Very poor }\end{array}$ & 112 & $\begin{array}{l}10(9) \\
53(47) \\
45(40) \\
4(4) \\
0\end{array}$ \\
\hline $\begin{array}{l}\text { How would you describe your own reaction to performing a physical examination on a psychiatric } \\
\text { patient? }\end{array}$ & $\begin{array}{l}\text { Enjoyable } \\
\text { Neutral } \\
\text { Unpleasant }\end{array}$ & 116 & $\begin{array}{l}18(16) \\
83(71) \\
15(13)\end{array}$ \\
\hline $\begin{array}{l}\text { Since starting work in psychiatry, have your physical examination skills improved, remained the } \\
\text { same or deteriorated? }\end{array}$ & $\begin{array}{l}\text { Improved } \\
\text { Remained the same } \\
\text { Deteriorated }\end{array}$ & 117 & $\begin{array}{l}6(5) \\
27(23) \\
84(72)\end{array}$ \\
\hline $\begin{array}{l}\text { Do you think that it is possible for a practising psychiatrist to maintain/improve his or her physical } \\
\text { examination skills? }\end{array}$ & $\begin{array}{l}\text { Yes } \\
\text { No } \\
\text { Not sure }\end{array}$ & 116 & $\begin{array}{l}98(86) \\
16(14) \\
2(2)\end{array}$ \\
\hline $\begin{array}{l}\text { Do you think that the ability to perform an adequate physical examination should be a part of a } \\
\text { psychiatrist's core competencies? }\end{array}$ & $\begin{array}{l}\text { Yes } \\
\text { No } \\
\text { Not sure }\end{array}$ & 117 & $\begin{array}{l}114(97) \\
2(2) \\
1(1)\end{array}$ \\
\hline $\begin{array}{l}\text { Do you think that Psychiatrists should have to maintain their physical examination skills } \\
\text { throughout their career e.g. by attending refresher courses? }\end{array}$ & $\begin{array}{l}\text { Yes } \\
\text { No } \\
\text { Not sure }\end{array}$ & 116 & $\begin{array}{l}102(88) \\
12(10) \\
2(2)\end{array}$ \\
\hline $\begin{array}{l}\text { Do you think that a teaching session on the physical examination in psychiatry should be included } \\
\text { in the psychiatric trainees' induction course? }\end{array}$ & $\begin{array}{l}\text { Yes } \\
\text { No } \\
\text { Not sure }\end{array}$ & 116 & $\begin{array}{l}88(76) \\
26(22) \\
2(2)\end{array}$ \\
\hline $\begin{array}{l}\text { Do you think that the physical examinations performed on psychiatric patients should be done by } \\
\text { another type of professional e.g. a physician, or a psychiatric nurse practitioner? }\end{array}$ & $\begin{array}{l}\text { Yes } \\
\text { No } \\
\text { Not sure }\end{array}$ & 116 & $\begin{array}{l}29(25) \\
79(68) \\
8(7)\end{array}$ \\
\hline
\end{tabular}


